\title{
KAJIAN KOMUNIKASI PEMASARAN TERPADU (IMC) "SPAKBOR BECAK SEBAGAI UNCONVENTIONAL MEDIA ADVERTISING DI YOGYAKARTA"
}

\author{
I Nengah Jeffry Prana Widnyana \\ Program Studi Desain Komunikasi Visual \\ Fakultas Seni Rupa ISI Yogyakarta
}

\begin{abstract}
This research is categorized as a descriptive research which shows the situation of marketing condition in Yogyakarta. The effort to describe the facts in the fields is not only collecting and arranging the data, but also analyzing and interpreting the data meanings related to the rhetoric theories. This research is aimed to discover and analyze companies which use pedicabs' spakbor as their advertising and marketing media. The researcher collected the data by taking audio and visual documentation and interviewing the resource persons, such as the cycle rickshaw, the pedicabs' owners, and the companies itself which utilize pedicabs' spakbor as their advertising and promoting media. Under consideration and activities which would be done, the samples which were used by the researcher are Warung Bakmi Jowo P.Jiko, Param Minyak Gosok Enggal Sehat, Rebranding Jogja Istimewa and Hotel Grand Aston Yogyakarta.

The result of this research shows that both companies in Yogyakarta begin to realize the importance of promoting activities. The change of modern marketing causes all companies have to be careful to consumers and make more efforts in creating and doing Integrated Marketing Communication in order to build longterm relationship, maintain and strengthen the brands.
\end{abstract}

Keywords: Integrated Marketing Communication, Pedicabs, Becak, Unconventional Media, Advertising.

\section{PENDAHULUAN}

\section{A. Latar Belakang}

Perkembangannya amat sangat cepat mengikuti perkembangan zaman. Yang umumnya periklanan diaplikasikan dalam poster yang ditempelkan dipapan pengumuman atau dinding, brosur yang ditebarkan dan dibagi-bagikan, atau iklan yang dicetak besar dalam billboard mungkin memberi sedikit kelemahan baik kelemahan hanya orang sekitar yang melihat, maupun kelemahan harus mencetak lebih banyak agar banyak orang mengetahuinya. Akan tetapi berbeda dengan iklan di Yogyakarta yang semakin kreatif dengan menggunakan media-media baru atau media yang ada disekitar masyarakat, salah satunya dengan menggunakan alat transportasi tradisional berupa becak, dimana spakbor (slebor/ tepong) becak digunakan sebagai media untuk beriklan. Di samping jumlah becak lebih banyak, dan lebih luar jangkauannya, peneliti lebih memilih penelitian akan spakbor becak, dimana spakbor becak yang lebih sering digunakan untuk media periklanan. Penulis tertarik akan cara beriklan 
melalui alat transportasi menjadi media komunikasi. Becak merupakan alat transportasi tradisional dan menjadi salah satu dari beberapa ikon milik Yogyakarta yang kini menjadi media periklanan. Alat transportasi becak sekarang ini mengalami perubahan dan menjadi ketertarikan utama bagi penulis untuk meneliti dan meninjau lebih dekat lagi. Hampir seluruh becak di Indonesia dilukis manual, biasanya bergambar pemandangan dan ornamen, identitas suatu paguyuban/kelompok, maupun curahan hati penarik becak itu sendiri dan memiliki warna yang menarik dengan warna kontras dan menyala. Namun akhir-akhir ini semuanya berubah, banyak becak yang kini bekerjasama dengan suatu perusahaan tertentu di Yogyakarta untuk menambah pendapatan mereka. Hal ini terlihat adanya brand perusahaan yang menggunakan jasanya di bagian spakbor becak. Berkaitan dengan ilmu desain komunikasi visual, penelitian ini menemukan adanya media dalam karakter becak Yogyakarta yang menjadi media branding di dalam transportasi tradisional yaitu spakbor (tepong/ slebor) becak.

Kasus ini yang menjadikan peneliti semakin tertarik akan pemilihan spakbor becak sebagai unconventional media advertising di Yogyakarta, disebut demikian karena spakbor semakin marak digunakan sebagai media periklanan dari iklan komersil maupun iklan layanan masyarakat. Iklan komersil yang memilih spakbor becak sebagai media periklanan kebanyakan digunakan oleh perhotelan dengan mencantumkan nama hotel dibagian spakbor becak. Selain perhotelan ternyata spakbor becak juga digunakan banyak pihak lainnya seperti politik (nasdem), carrefour, provider seluler (XL, Telkomsel dan Axis), toko (mirota batik), warung makan (warung bakmi Jawa P. Jiko), obat tradisional (Param Minyak Gosok Enggal Sehat) dan lain-lainnya. Hal ini menjadikan peneliti semakin tertarik akan alasan kenapa spakbor becak dipilih sebagai media promosi di Yogyakarta. Jika kita amati, fenomena ini tentunya ada hubungannya dengan pembahasan IMC (Integrated Marketing Communication).

IMC adalah sebuah konsep komunikasi yang terencana, terintegrasi dan diterapkan dalam berbagai bentuk komunikasi pemasaran untuk memberikan pemahaman dan dampak yang maksimal melalui konsistensi pesan komunikasi kepada konsumen, pelanggan ataupun pihak lain yang relevan dengan barang atau jasa yang dikomunikasikan. Hal ini yang menjadikan peneliti tertarik dalam melakukan penelitian mengenai IMC yang memilih spakbor becak 
sebagai unconventional media advertising di Yogyakarta. Kasus sederhana ini ternyata belum ada yang membahas akan spakbor becak yang telah menjadi unconventional media advertising di Yogyakarta. Oleh sebab itu, peneliti memilih kasus ini sebagai topik dalam penelitian. Peneliti juga meyakinkan bahwa penelitian ini sesungguhnya menarik karena tanpa sadar dalam kasus ini banyak menerapkan ilmu desain komunikasi visual guna memecahkan masalah dalam masyarakat dan menjadikan iklan yang diiklankan lebih efisien dan semakin menarik.

\section{Rumusan Masalah}

Berdasarkan latar belakang yang telah dijabarkan dapat dideskripsikan permasalahan yang ada, maka dapat dirumuskan permasalahannya sebagai berikut:

1. Aspek verbal dan visual seperti apa yang ada pada spakbor becak sehingga menjadi media unconventional advertising $\mathrm{di}$ Yogyakarta?

2. Bagaimana komunikasi pemasaran terpadu (IMC) pada spakbor becak sehingga terpilih menjadi media promosi?

\section{Tujuan Penelitian}

Penelitian ini bertujuan membongkar makna pada tiap elemen verbal maupun visual yang ada pada spakbor becak, alasan terpilihnya spakbor sebagai media promosi dan pemikiran IMC yang tersembunyi dalam fenomena spakbor becak sebagai media unconventional advertising di Yogyakarta. Melalui penelitian ini diharapkan akan terbuka luas pemahaman mengenai fakta periklanan yang ada di Yogyakarta mengenai transportasi tradisional (becak).

\section{Teknik Analisis Data}

Menganalisis secara rinci data yang terkumpul melalui wawancara, studi pustaka, dan pengalaman pribadi saat melakukan observasi secara langsung merupakan pengolahan data yang dilakukan penulis. Data yang terkumpul, kemudian dipilih berdasarkan kebutuhan penulis. Penelitian dengan metode kualitatif deskriptif hanya sebatas pada pengumpulan data. Data tersebut setelah tekumpul kemudian dianalisis menggunkan teori retorika guna mencari tahu makna-makna yang terkandung atau pesan tersembunyi yang ingin disampaikan dan teori Ducan dan Moriarty dengan tiga tingkatan dalam membentuk pesan dimana suatu perusahaan diharuskan untuk lebih memfokuskan dirinya dalam memperoleh, mempertahankan dan mengembangkan hubungan perusahaan dengan pelanggan. 


\section{PEMBAHASAN DAN HASIL ANALISA}

\section{Sampel 1}

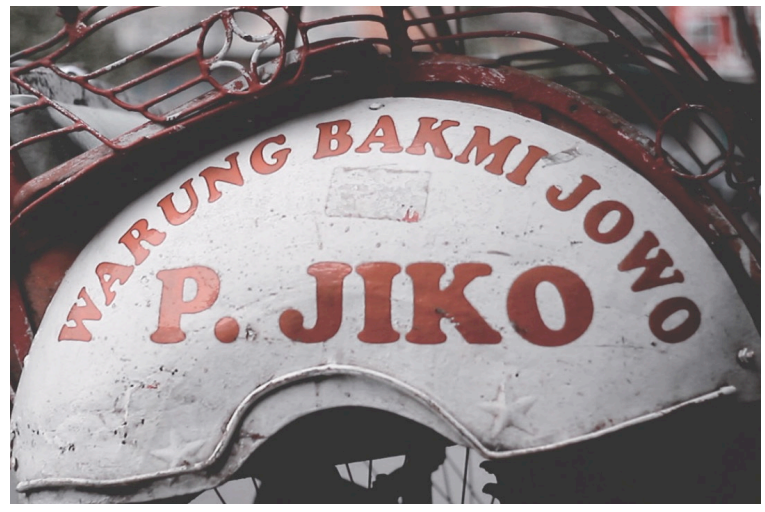

Gambar 1 Warung Bakmi Jowo P. Jiko, Becak Pak Jiko

Sumber: Dokumentasi penulis (24 Februari 2015)

Warung Bakmi Jowo P. Jiko adalah tempat penyewaan becak Yogyakarta yang ada di jalan Mataram tepatnya di kelurahan Suryatmajan Rt. 28/ Rw. 10, Yogyakarta. Becak yang disewakan dengan harga $\mathrm{Rp}$. 5.000,- untuk satu hari satu malam. Pemilik penyewaan becak tersebut bernama Rajiko, dan biasa dipanggil pak Jiko adalah seorang pria paruh baya yang berasal dari Wonosari, berusia 68 tahun yang sehari-harinya berprofesi sebagai tukang tambal ban sepeda atau motor dan warung klontong berukuran $3 \times 2$ meter menjajakan minuman, rokok dan sedikit jajan anak-anak. Dimalam harinya tambal ban tersebut menjadi tempat warung makan bakmi Jawa milik istrinya yang menjadi usaha bersama beliau dan dibantu putri terakhir dari tiga saudara. Pak Jiko sebagai juru masak, dan istrinya membantu beliau dan mengurus pembayaran atau sebaliknya, sedangkan putrinya membantu membuat minuman. Sebelum pak Jiko menjadi seorang tukang tambal ban, beliau berprofesi sebagai tukang las. Perjuangannya mengais rezeki dipekerjaannya tersebut membuatnya memilih investasi berupa becak, dari yang pertama ia hanya memiliki 5 becak hingga kemudian menjadi 10 becak. Namun sayangnya beberapa kali becaknya tak kembali, ia menceritakan beberapa tahun lalu becaknya hilang dua sekaligus, tak lama kemudian peristiwa itu terulang kembali dengan hilangnya satu becak. Hal ini membuat pak Jiko memutuskan untuk menjual beberapa becak dan menyisakan hanya lima becak saja miliknya agar mudah mengawasinya. Setelah menjual becaknya, dari hasil penjualan itu pak Jiko memperbaiki becak miliknya dan melabeli becaknya dengan label "WARUNG BAKMI JOWO P. JIKO” sebagai tanda bahwa itu becak miliknya dan menjadikannya beda dengan becak lain.

Font yang digunakan termasuk dalam kelas serif yang berjenis Cooper Black. Font yang dibuat sekitar tahun 1921 merupakan font berbentuk tumpul dan bulat membuat kesan yang memiliki nilai konotatif sebagai kehangatan namun tetap ramah. Kesan 
tersebut mencerminkan sosok pemilik yang bernama Rajiko yang biasa dipanggil dengan Pak Jiko (P. JIKO), orang yang berprofesi penawaran jasa tambal ban, rumah makan bakmi Jawa dan penyewaan beberapa becak.

\section{Sampel 2}

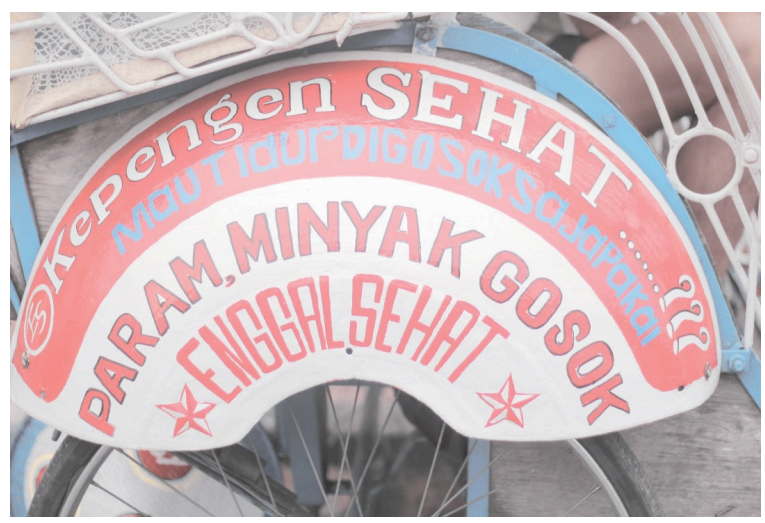

Gambar 2 Param, Minyak Gosok Enggal Sehat, Becak Pak Ngatiran

Sumber: Dokumentasi penulis (26 Februari 2015)

Gambar diatas adalah gambar spakbor milik becak pak Ngatiran yang berusia 58 tahun, seorang pemilik becak yang bertempat tinggal di rusunawa yang ada di jalan Juminah Yogyakarta. Beliau tinggal di rusun sejak tahun 2006. Beroprasi di sekitar jalan Juminah hingga jalan Bausasran atau stasiun Lempuyangan. Beliau berprofesi sebagai penarik becak sejak tahun $80 \mathrm{an}$. Awal tahun 2015 pak Ngatiran menjalin kerjasama dengan pak Tris. Pak Tris meminjam spakbor becak milik pak Ngatiran selama satu tahun dengan biaya Rp. 500.000,- dibayar lunas. Bapak M. Trisno S. atau yang terkenal dengan sebutan Pak Tris merupakan pengusaha berupa industri kecil atau rumahan yang bergerak pada penjualan obat tradisional dan pengobatan alternatif, salah satu produk unggulanya adalah param minyak gosok dan jasa pijat totok darah yang terletak di daerah Bausasran DN 3/ 773, Yogyakarta. Beliau sudah sejak tahun 2005 memproduksi param minyak gosok dan terdaftar di badan POM ditahun 2010. Sejak itu juga pak Tris mulai memproduksi param minyak gosoknya secara masal dirumah yang terbilang sederhana beserta istri tercintanya. Produk param minyak gosok miliknya dijual dengan harga Rp. 20.000,- per botolnya. Produk produknya dipasarkan di rumahnya dan di beberapa outlet seperti tukang jamu tradisional, toko penjual obat tradisional/ herbal, dan apotik - apotik kecil sekitar Yogyakarta.

Pak Tris adalah orang awam yang bukan mahir dalam bidang periiklanan, namun beliau sadar akan sebuah pemasaran. Jika ditahun sebelum - sebelumnya beliau hanya menggunakan brosur, kalender ataupun banner dalam berpromosi yang dipasang di rumah makan ataupun toko obat tradisional/ herbal, diawal tahun 2015 pak Tris mulai menggunakan media massa seperti memasang iklan di JogjaTv yang katanya perbulan dikenakan biaya Rp. 1.800.000,- dan 
ditayangkan sekitar pukul 11.00 WIB hingga 12.00 WIB. Beliau juga memasang iklan di dua radio lokal AM, tepatnya dalam acara yang bernuansa pewayangan dengan biaya Rp. 500.000,- per bulan untuk satu stasiun radio. Media selanjutnya yang membuat menarik penulis adalah media spakbor becak yang dikontraknya selama satu tahun sebesar Rp. 500.000,-. Menurutnya pak Tris, sebenarnya sudah lama terpikirkan akan pentingnya promosi agar memperkenalkan produknya di sekitar Yogyakarta namun dikarenakan promosi juga memakan biaya, beliau hanya menggunkan promosi media cetak saja. Keuntungan yang beliau peroleh dari awal beliau merintis industri kecilnya inilah yang akhirnya bisa untuk berpromosi. Alasan pak Tris menggunakan becak sebagai media promosinya juga sebenarnya sederhana, yaitu cuma ikut-ikutan. Beliau terinspirasi bentuk promosi hotel sekitar Yogyakarta yang sebagaian besar menggunakan becak sebagai alat promosi perusahaannya.

Tipografi vernakular yang digunakan dalam desain spakbor becak tersebut merupakan tipografi yang terlahir dari budaya lokal asli Indonesia dimana sebagai sumber ide pembuatan jenis font dalam suatu desain. Tipografi jenis ternyata masih dipertahankan dalam pembuat ilustrasi atau karya pada spakbor becak, salah satunya pada spakbor becak milik Pak Ngatiran. Tipografi vernakular masuk dalam bagian street graphics, dimana biasa digunakan dan dijumpai pada papan promosi, spanduk toko dan warung makan kaki lima. Param minyak gosok ini merupakan usaha rumahan yang ternyata mulai peduli akan adanya kegiatan promosi. Bagi pemilik usaha param minya gosok ini, kegiatan promosi membantu memperkenalkan produknya ke masyarakat. Usaha yang telah dirintis sejak tahun 2005 ini ternyata baru mulai mengiklankan produknya pada tahun 2015. Beliau mengiklankan di JogjaTv, radio lokal, media cetak seperti brosur, spanduk dan kalender, dan mengunakan media spakbor becak sebagai kegiatan promosinya. Usaha yang langsung besar-besaran untuk usaha rumahan tersebut ternyata menjadi kegiatan yang unik karena mengajak tetangganya yang beberapa dari mereka berprofesi tukang becak. Mereka dilatih layaknya orang yang berpendidikan untuk menjadi seorang pemasaran (salesman). Mereka membawa beberapa produk dan menawarkan pada para penumpang mereka. Mereka juga memberikan sedikit contoh produk bagi yang penasaran dan mau mencobanya. Sekalipun tidak semua yang menjalankan secara demikian, namun pak Ngatiran adalah salah 
satu penarik becak yang aktif dalam promosi param minyak gosok tersebut.

Idola hidupnya adalah Eyang Semar, Eyang Semar adalah tokoh lokal dari pewayangan budaya Jawa. Ditambah dengan penggunaan tipografi vernakular dalam desain spakbornya yang digarap dengan manual memberi kesan budaya tradisional di zaman teknologi yang sudah modern sekarang ini. Dari kedua hal tersebut menguatkan karakter usaha pak Tris yang semuanya berhubungan dengan tradisional, obat tradisional dan pijat alternatif totok darah (pengobatan tradisional).

\section{Sampel 3}

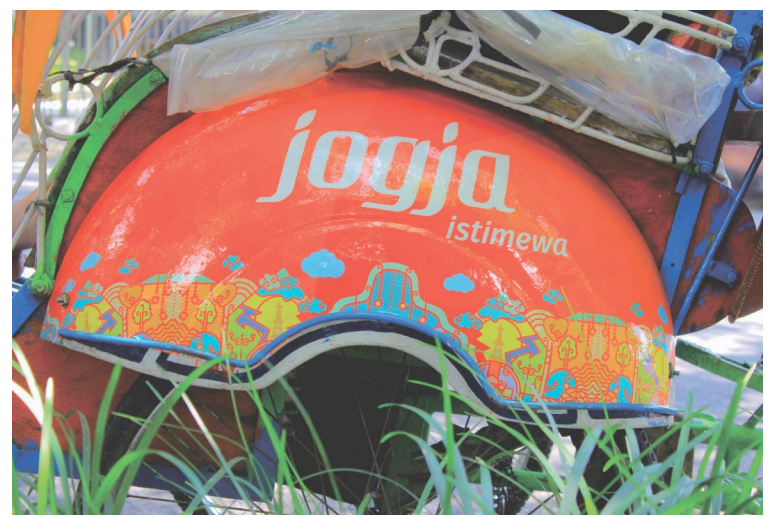

Gambar 3 Jogja Istimewa, Becak Pak Sarbini Sumber: Dokumentasi penulis (11 Maret 2015)

Tim Sebelas bersama Gubernur DIY telah menentukan logo baru Yogyakarta dan sekaligus menjawab kontroversi rebranding logo Yogyakarta. Jogja Istimewa merupakan wujud logo Yogyakarta yang baru hasil rembug logo atau musyawarah bersama. "Jogja Istimewa," demikian logo sekaligus tagline baru dengan desain warna merah menyala. Tim menyebut desain logo itu mengadaptasi dari aksara Jawa yang dimodernisasi. Warna merah bata (C:0 M:100 Y:100 K:10): berasal dari warna lambang Keraton Kasultanan Yogyakarta. Simbol keberanian, ketegasan dan kebulatan tekad. Font mengadaptasi aksara Jawa. Simple dan dinamis sebagai manifestasi semangat youth, women dan netizen. Tagline sengaja tidak menggunakan bahasa asing karena menghadirkan kebanggaan tersendiri dengan menggunakan Bahasa Indonesia. Memuat sembilan cita-cita pembangunan Yogyakarta (Jogja Renaissance) di bidang pendidikan, pariwisata, teknologi, ekonomi, energi, pangan, kesehatan, keterlindungan warga serta sektor tata ruang dan lingkungan. 1 Sembilan cita-cita itu tergambar pada bagian bawah logo berbentuk vector. Terdapat 20 becak Jogya Istimewa seperti di atas. Becak tersebut milik pak Sarbini, ia menadapatkan uang ganti sebesar Rp. 115.000,- untuk bersedia membawa iklan tersebut. Iklan dengan bentuk scotlite ternyata lebih efisien

\footnotetext{
1 http://jogja.tribunnews.com/2015/02/06/ini-maknadan-filosofi-di-balik-logo-baru-jogja-istimewa, diakses pada tanggal 12 Maret 2015 pada pukul 03.00 WIB.
} 
dalam pengerjaannya. Waktu penggarapan, biaya pembuatan dan umur iklannya pun cukup dibilang lumayan dibandingkan dengan cara yang manual. Kesan yang diberikannyapun sesuai dengan makna Jogja Istimewa yang ingin menghadirkan teknologi modern dengan budaya lokal dimana menghadirkan hasil teknologi digital yang membantu pengerjaan namun tetap terlihat tradisional saat digabungkan dengan becak Yogyakarta. Becak ini hanya beroprasi sekitar kota baru, gramedia dan stasiun lempuyangan.

\section{Sampel 4}

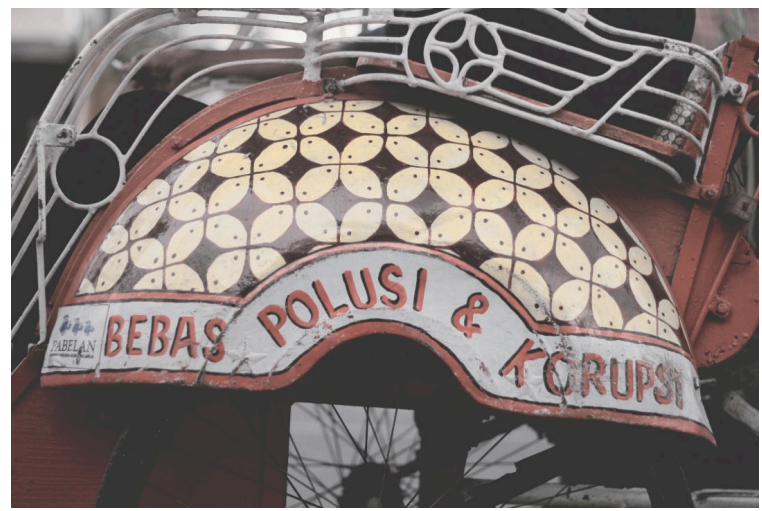

Gambar 4 Bebas Polusi \& Korupsi, Bapak Ari Sumber: Dokumentasi penulis (02 Maret 2015)

Sejumlah 30 becak model anti korupsi, yaitu dengan tulisan pesan anti-korupsi pada bagian slebor hari Rabu, 23 Maret 2014 diluncurkan di Yogyakarta oleh Majelis Pemberdayaan Masyarakat (MPM) Pusat Pimpinan Muhammadiyah bekerjasama dengan Komisi Pemberantasan Korupsi (KPK). Dari 30 becak tersebut, 20 diantaranya merupakan bantuan PP Muhammadiyah, lima becak bantuan mantan walikota Yogyakarta Herry Zudianto, dua dari mahasiswa Universitas Muhammadiyah Yogyakarta dan selebihnya dari perbankan serta LSM. Ketua MPM, Said Tuhulele menjelaskan pihak MPM telah bekerjasama dengan memberikan bimbingan kepada komunitas penarik becak di kawasan Jalan Ahmad Dahlan Yogyakarta atau dikenal dengan paguyuban Pabelan. ${ }^{2}$ Mereka dilibatkan dalam kampanye anti-korupsi dari kalangan masyarakat kelas bawah. Mengingat korupsi itu menjadi masalah besar kita, usaha sosialisasi usaha anti korupsi memang harus lakukan. Manfaatkan becak sebagai wahana untuk sosialisasi sikap anti korupsi. Berdasarkan wawancara penulis pada tukang becak, ternyata becak yang mereka pakai adalah becak gratis. Siapapun bisa menggunakan becak tersebut dengan ketentuan ikut menjadi anggota Pabelan tanpa dipungut biaya apapun.

Becak di atas adalah salah satu becak milik Pabelan dengan penarik becak bernama

\footnotetext{
${ }^{2} \mathrm{http} / / /$ infokorupsi.com/id/korupsi.php?ac=11573\&l=k pk-dan-muhammadiyah-luncurkan-becak-antikorupsi, di akses pada 3 Maret 2015, pukul 20.10 WIB
} 
Ari Raharjo, seorang ayah kelahiran 25 Januari 1972 yang sudah dikaruniai dua putri bertempat tinggal di Mangunegara pb 1/ 247 yk RT 078/ 018, Panembahan, Keraton, Yogyakarta. Beliau menjadi anggota Pabelan sejak terselenggaranya kegiatan kampanye becak anti polusi dan korupsi pada tanggal 23 Maret 2014 lalu. Awalnya pak Ari memang sudah berprofesi sebagai penarik becak, tetapi becak yang dibawanya merupakan becak sewaan. Adanya kegiatan kampanye telah membantu baginya atas pinjaman becak gratis dengan syarat menjadi anggota Pabelan guna pendataan siapa saja anggotanya. Paguyuban Pabelan merupakan organisasi yang dibentuk oleh beberapa penarik becak untuk sebuah pengakuan dan identitas sebagai penarik becak dan menjaga 30 becak yang merupakan hasil sumbangan dari beberapa pihak dalam acara anti korupsi tersebut. Paguyuban Pabelan juga membentuk iuran bulanan (arisan) sebesar Rp. 30.000,- perbulannya untuk iuran perbaikan becak, kesehatan, maupun simpan pinjam bagi yang membutuhkan. Setiap harinya pak Ari berprofesi sebagai penarik becak yang beroprasi dari pukul 09.00 WIB 22.00 WIB, dan jalur yang biasa beliau mangkal seputar jalan KH. Ahmad Dahlan hingga Museum Perjuangan Yogyakarta Jl. Kol. Sugiyono.
Spakbor becak digarap dengan cat besi dengan warna dasar putih untuk ilustrasi verbal BEBAS POLUSI \& KURUPSI dengan gaya vernakular, dinama penggarapannya secara manual untuk memberi kesan mempertahankan budaya lokal. Untuk ilustrasi visualnya dengan warna dasar merah dengan ilustrasi batik kawung berwarna kuning dan coklat. Warna kuning adalah warna cerah yang sering digunakan untuk pemberitahuan dan seringkali digunakan untuk mendapatkan perhatian banyak orang. Hal ini yang mungkin dipilihnya warna kuning agar orang dapat melihat jelas apa yang ingin ditunjukan oleh pembawa pesan dengan spakbor becak kepada pembaca. Sedangkan warna coklat adalah salah satu warna yang mengandung unsur bumi (tanah). Unsur bumi (tanah) menunjukan agar pembaca selalu ingat akan tanah kelahiran atau tanah air mereka, berharap pembaca tak pernah lupa dalam membangun perbaikan asal usul mereka. Semua makna tersebut juga semakin jelas dengan adanya batik bermotif kawung. 


\section{Sampel 5}

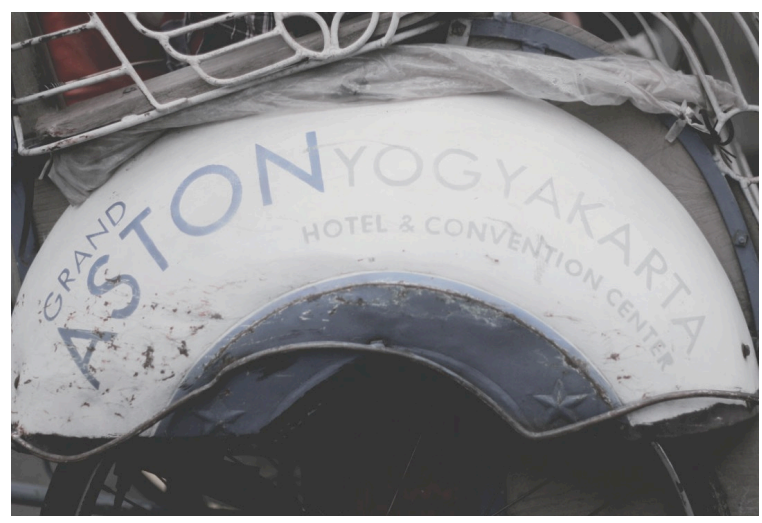

Gambar 5 Grand Aston Yogyakarta Hotel \& Convention Center (2011), Becak Pak Ngatmin Sumber: Dokumentasi penulis (01 Maret 2015)

Pada tahun 2011 merupakan tahun di mana grand opening hotel Grand Astone di Yogyakarta. Terdapat 50 becak yang ikut meramaikan opening tersebut. Setiap becaknya mendapatkan Rp. 100.000,- sebagai uang ganti peminjaman becak untuk pengecatan selama tiga hari. Setelah itu becak dikembalikan pada pemiliknya. Satu minggu setelah opening terdapat 20 becak menjadikan dirinya menjadi tenaga promosi pemasaran resmi dan menjadi keluarga besar hotel Grand Aston Yogyakarta. Becak Grand Aston Yogyakarta yang resmi hanya ada di depan hotel, sisanya bukan menjadi bagian dari anggota sekalipun mereka berada disepanjang jalan Solo. Relawan yang menjadi keluarga Grand Aston Yogyakarta hanya mendapatkan seragam sebanyak tujuh seragam. Tiap harinya mereka mengenakan seragam yang berbeda warna. Dikarenakan Hotel Grand
Aston minim parkiran, akhirnya parkir becak hanya ada di depan pintu keluar sebelah timur. Parkiran becak hanya untuk 4 becak, sisanya mengantri di sepanjang jalan Solo. Antrian berdasarkan siapa yang terlebih dahulu datang.

Gambar di atas adalah gambar spakbor becak milik pak Ngatmin yang ikut dalam kegiatan grand opening Hotel Grand Aston tahun 2011 lalu. Pak Ngatmin berprofesi sebagai penjual angkringan yang ada di dekat pintu keluar Superindo. Pak Ngatmin berjualan bersama istri dan anaknya. Apabila ada penumpang maka pak Ngatmin mengantarkannya terlebih dahulu dan angkringannya diserahkan kepada istrinya. Setelah selesai mengantar penumpang, pak Ngatmin kembali ke tempat ia berjualan. Ia memutuskan ikut dalam kegiatan grand opening dengan menyerahkan becaknya dikarenakan imbalan yang diterimanya, baginya imbalan itu menjadi masukan tanpa harus mengantar penumpang dan mendapatkan penampilan becaknya yang menjadi baru lagi (perbaikan cat becak).

Narasumber lainnya yaitu pak Wagiman asal Wonosari yang merupakan anggota Hotel Grand Aston. Baginya mendapatkan penumpang dari Hotel Grand Aston sudah cukup senang sekalipun mereka memiliki harapan besar dari Hotel Grand 
Aston. Harapan yang ingin lebih dipandang dan bisa dibedakan akan anggota Hotel Grand Aston yang resmi dengan becak lainnya yang memiliki desain serupa namun tidak termasuk dalam anggota.

Layout diatas menggambarkan ke tegasan dan ekonomis. Hal ini terlihat dengan penggunaan jenis tipografi Century Gothic. Logo dengan warna biru abu-abu merupakan warna yang sering digunakan oleh institusi bisnis. Dimana kita ketahui Grand Aston merupakan perusahaan perhotelan berbintang yang memberi pelayanan baik dengan nuansa keserhanaan namun tetap maskulin. Kesan ekonomis terlihat dari pengerjaan spakbor becak yang hanya menggunakan cat dasar sebagai dasarannya dan pengunaan teknik stensil sebagai penulisan Hotel Grand Aston, dimana menggunakan mall yang sudah dilubangi dan kemudian di brush berdasarkan warna yang diinginkan. Pengerjaan itu memakan waktu tiga hingga empat hari dikarenakan yang di cat tidak hanya spakbornya saya, melainkan hingga rangka becaknya. Karena becaknya dalam masa perbaikan dan pengecatan, maka para penarik becak mengambil hari libur selama penggarapan tersebut.

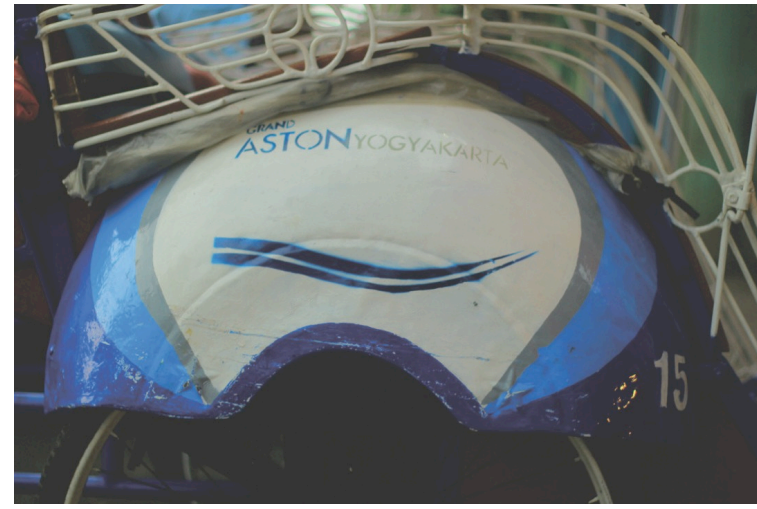

Gambar 6 Grand Aston Yogyakarta Hotel \& Convention Center (2014) Becak Pak Wagiman Sumber: Dokumentasi penulis (01 Maret 2015)

Pada tahun 2014 tepatnya pada saat libur lebaran ada perbaikan becak dari pihak hotel. Para becak hanya mendapatkan Rp. 75.000,- untuk perbaikannya. Desain yang seadanya merupakan desain dari hasil musyawarah paguyuban Grand Aston. Mereka berkumpul dan memperbaiki becaknya sendiri dalam satu tempat salah satu anggota. Cara dalam memilih becak sebagai media promosinya terbilang ekonomis namun berjangka panjang. Hal ini tidak sebanding dengan pendapatan yang mereka peroleh dan tidak seperti karakter brand yang menghadirkan keunikan ditengah modernitas. Kasus lainnya yang serupa namun bukan perusahaan perhotelan adalah provider seluler XL, Telkomsel, dan Axis. Berdasarkan hasil pengumpulan data yang didapat dari pengakuan pada narasumber dengan label perusahaan tersebut ternyata sama, mereka hanya mendapatkan Rp. 
100.000,- saat acara peresmian dibukanya XL Center dan lainnya.

\section{KESIMPULAN}

Penelitian yang penulis buat dengan judul "Kajian Komunikasi Pemasaran Terpadu (IMC) Spakbor Becak Sebagai Unconventional Media Advertising Di Yogyakarta" bermaksud untuk mengetahui tentang makna, tujuan dan peran komunikasi dalam proses pemasaran (IMC) pada kasus promosi yang menggunakan media spakbor becak di Yogyakarta. Paradigma yang jarang bahkan enggan digunakan ini sebenarnya telah menuntut komunikasi perusahaan dan pelanggan sejak dari prapenjualan, penjualan, konsumsi hingga paska konsumsi. Komunikasi pemasaran terpadu (IMC) telah membangun komunikasi dan kepercayaan pelanggan pada kejujuran, integritas dan situasi. Karakter orang Yogyakarta yang terkenal dengan kesederhanaan, ramah, jujur, dan apa adanya menjadi kelebihan dalam pembentukan kepercayaan pelanggan dengan prusahaan. Keistimewaan masyarakat Yogyakarta dalam berperilaku dan berkomunikasi yang berkesan lemah lembut juga menjadi faktor yang mempengaruhi pelanggan dalam keputusan membeli, memakai atau menyukai pelayanan yang diberikan.
Berdasarkan hasil laporan penelitian dan analisis data mengenai pelaksanaan strategi komunikasi terpadu (Integrated Marketing Communications) pada beberapa perusahaan yang menggunakan media spakbor becak sebagai media beriklan di Yogyakarta, maka penulis dapat mengambil kesimpulan sebagai berikut:

1. Alasan dan tujuan para pengiklan yang menggunakan spakbor becak sebagai media promosi di Yogyakarta adalah sarana identifikasi (branding), sarana informasi, sarana promosi, sarana motifasi dan pengutaraan emosi.

2. Dalam membangun dan memperkuat brand, sejauh ini perusahaan yang ada di Yogyakarta baik itu usaha kecil maupun besar telah berupaya optimal untuk melakukan komunikasi pemasaran yang terintegrasi. Artinya, perusahaan ini telah memadukan berbagai elemen bauran komunikasi pemasaran menjadi satu kesatuan. Upaya yang senantiasa dilakukan agar pesan yang disampaikan ke audiens dapat terarah dan mencapai satu titik kontak sehingga audiens tidak mengalami kebingungan. Kombinasi dari beberapa teknik komunikasi pemasaran juga memberikan sinergi dan kesempatan yang lebih besar untuk menambah jumlah waktu bertemu dengan pelanggan dan 
menanamkan citra positif brand maupun perusahaan dalam benak pelanggan. Pelaksanaan strategi komunikasi pemasaran terpadu dengan melibatkan becak sebagai media promosi merupakan upaya jangka panjang yang telah terorganisir dengan terbentuknya suatu komunitas atau biasa dikenal dengan paguyuban, baik itu atas dasar inisiatif para penarik becak maupun sengaja dibentuk oleh para pengiklan untuk menjadi bagian tenaga promosi dan fasilitas perusahaan. Upaya yang bisa dibilang efektif dan efisien sesuai dengan kebutuhan brand, baik dalam segi wisata, fasilitas transportasi, salesman dan informan, loyalitas merek, dan persepsi pelanggan terhadap perusahaan. Hampir semua perusahaan yang mengiklankan iklannya dibecak hanya bayar sekali untuk seterusnya, tanpa ada kontrak atau waktu yang jelas. Hal ini memberikan keuntungan para pengiklan yang memanfaatkan keadaan perilaku dan pemikiran orang awam (penarik becak), karena mereka tahu bahwa perilaku para penarik becak yang malas untuk memperbaiki becaknya dan lemahnya kesadaran akan hal mutualisme dalam hal kerja sama sehingga menguntungkan para pengiklan karena iklannya lebih ekonomis tanpa ada biaya pajak atau izin yang merepotkan dan menyita waktu. Penjelasan ini yang penyebabkan para pengiklan marak menggunakan becak sebagai media beriklannya.

3. Hasil yang diperoleh dari semua kegiatan perencanaan dan pelaksanaan strategi komunikasi pemsaran terpadu dapat dilihat dari bentuk dan kegiatan yang masih dilakukan hingga sekarang yaitu, masih setianya penarik becak menjadi tenaga promosi perusahaan yang pertama mengajak bekerja. Fenomena itu cukup membuat konsumen menjadi antusias dan loyal atau kesetiaan. Antusias tersebut diukur dari tingkat kesukaan, kepuasan dan kepercayaan yang diberikan oleh konsumen sehingga berpengaruh pada peningkatan penjualan dan image yang positif.

Hasil yang diperoleh lainnya adalah adanya persepsi kualitas, asosiasi merek, dan kesadaran merek. Persepsi kualitas mencerminkan persepsi pelanggan terhadap keseluruhan kualitas/keunggulan suatu produk atau jasa. Asosiasi merek menunjukan pencitraan suatu merek terhadap suatu kesan tertentu dalam kaitanya dengan kebiasaan, gaya hidup, manfaat, atribut produk, geografis, dan harga. Kebiasaan para konsumen pastinya membutuhkan 
transportasi jarak dekat, kebutuhan ini menjadikan mereka memilih becak sebagai alat transportasi umum jarak dekat. Gaya hidup ekonomis juga menjadikan para konsumen memilih becak sebagai alat transportasi yang terbilang ekonomis dibandingkan taksi yang lebih mahal atau bus Trans Jogja yang rutenya panjang sehingga lebih lama dan lebih jauh.

\section{DAFTAR PUSTAKA}

\section{Artikel}

[1] Andreas Maryoto. 24 April 2010, Panorama Sawah dalam Perspektif Sejarah Nusantara. Artikel. Indonesia history, social theory on resources for dilletantes.

\section{Buku}

[1] Azwar, MA, Saifuddin. Metode Penelitian, Pustaka Pelajar, 2004

[2] Burhan, M. Agus. Perkembangan Seni Lukis Mooi Indie samapai Persagi di Batavia, 1900 - 1942. Jakarta: Galeri Nasional Indonesia. 2008.

[3] Ebdi Sayoto, Drs. Sadjiman. Metode Perancangan Komunikasi Visual Periklanan, Yogyakarta: Media Pres, 2006

[4] Kasali, Rhenald. Manajemen Periklanan, Konsep dan aplikasinya di Indonesia, PT. Pustaka Utama Graffiti, Januari 1992

[5] Lombard, Denys. Nusa Jawa Silang Budaya. Jakarta: Penerbit Gramedia. 2008

[6] Moleong, M.A., Prof. Dr.Lexy J. Metode Penelitian Kualitatif Edisi Revisi, PT. Remaja Rosdakarya, Bandung, 2007
[7] PPPI, Tata Krama Periklanan Indonesia, 1977

[8] Pusat Pembinaan dan Pengembangan Bahasa Depdikbud, Kamus Besar Bahasa Indonesia, Balai Pustaka, Jakarta, 1998, h. 453

[9] Rangkuti, Freddy. Strategi Promosi Yang Kreatif dan Analisis Kasus Integrated Marketing Comunication, PT. Gramedia Pustaka Utama, 2009

[10] Sachari, Agus. Sosiologi Desain. Bandung: Penerbit ITB. 2002

[11] Sobur, Drs. Alex. Analisa Teks Media. Bandung, Penerbit: PT. Remaja Rosdakarya. 2001

[12] SS. Daryanto, Kamus Bahasa Indonesia Lengkap, Apollo, Surabaya, 1997

[13] Sutopo, H. B. Metodologi Penelitian Kualitatif, Dasar Teori Dan Terapannya Dalam Penelitian, Universitas Sebelas Maret, Surakarta, 2006, Edisi 2

[14] Wojowasito, Kamus Lengkap Inggris Indonesia Indonesia - Inggris. Bandung: Penerbit Hata, 1980

\section{Website}

[1] http://kraksaanupdate.blogspot.com/2010/12/sejarahbecak-dan-perkembangannya-saat.html, terakhir diakses pada tanggal 19 September 2014, pada pukul 09.00 WIB

[2] http://vinspirations.blogspot.com/2009/0 6/jenis-dan-fungsi-iklan.html, terakhir diakses pada tanggal 4 Mei 2014, pada pukul 21.30 WIB

[3] http://www.harianjogja.com/baca/2014/0 8/26/becak-bergambar-kondomberedar-di-jogja-530220, terakhir diakses pada tanggal 27 Agustus 2014, pada pukul 08.10 WIB

[4] http://www.radarjogja.co.id/mpmmuhammadiyah-gandeng-pabelanluncurkan-becak-antikorupsi/, terakhir diakses pada tanggal 25 April 2014, pada pukul 08.00 WIB 